\title{
KAJIAN PSIKOLOGI SASTRA DAN NILAI PENDIDIKAN KARAKTER NOVEL RANTAU 1 MUARA KARYA AHMAD FUADI SERTA RELEVANSINYA SEBAGAI MATERI AJAR APRESIASI SASTRA DI SMA
}

\author{
Nisa' A'fifatul Azizah, Herman J Waluyo, Chafit Ulya \\ Universitas Sebelas Maret \\ Surel: nisaafifatul01@gmail.com
}

\begin{abstract}
Abstrak: Penelitian ini bertujuan untuk mendeskripsikan dan menjelaskan (1) unsur intrinsik novel Rantau 1 Muara karya Ahmad Fuadi; (2) kondisi psikis tokoh yang digambarkan dalam novel Rantau 1 Muara karya Ahmad Fuadi menurut teori Sigmund Freud; (3) nilai-nilai pendidikan karakter yang terdapat dalam novel Rantau 1 Muara karya Ahmad Fuadi; (4) relevansi novel Rantau 1 Muara karya Ahmad Fuadi sebagai materi ajar apresiasi sastra di SMA. Penelitian ini menggunakan metode kualitatif deskriptif dengan pendekatan psikologi sastra. Pengumpulan data dilaksanakan dengan teknik analisis dokumen dan wawancara mendalam. Uji validitas data menggunakan teknik triangulasi teori. Analisis data menggunakan teknik analisis mengalir yaitu berupa reduksi data, penyajian data, dan penarikan simpulan. Hasil penelitian adalah (1) unsurunsur intrinsik yang membangun novel Rantau 1 Muara yaitu tema, penokohan, plot/ alur, latar/ setting, dan sudut pandang pengarang; (2) kondisi kejiwaan yang dialami oleh tokoh-tokoh dalam novel Rantau 1 Muara dipengaruhi oleh tiga unsur yaitu id, ego, dan superego; (3) nilai-nilai pendidikan karakter yang terdapat dalam novel Rantau 1 Muara ada 13 nilai diantaranya religius, jujur, toleransi, disiplin, kerja keras, mandiri, rasa ingin tahu, semangat kebangsaan, cinta tanah air, bersahabat/ komunikasi, gemar membaca, peduli sosial, dan tanggung jawab; (4) novel Rantau 1 Muara dapat digunakan sebagai alternatif materi ajar apresiasi sastra di SMA.
\end{abstract}

Kata Kunci: psikologi sastra, nilai pendidikan karakter, materi ajar

\section{LITERATURE PSYCHOLOGY STUDY AND CHARACTER EDUCATION VALUE OF RANTAU 1 MUARA NOVEL BY AHMAD FUADI AND ITS RELEVANCE AS LEARNING MATERIAL OF LITERATURE APPRECIATION IN SENIOR HIGH SCHOOL}

\begin{abstract}
This study aims to describe and explain (1) the intrinsic element of novel Rantau 1 Muara by Ahmad Fuadi, (2) the emotional condition of the character depicted in the novel Rantau 1 Muara by Ahmad Fuadi according to Sigmund Freud's theory, (3) the values of character education contained in the novel Rantau 1 Muara by Ahmad Fuadi, (4) the relevancy of novel Rantau 1 Muara by Ahmad Fuadi as a teaching material for literary appreciation class in Senior High School level. This study used a descriptive qualitative method with literary psychology approach. Data collection was carried out with document analysis techniques and indept interviews. The validity data test has been done using triangulation theory technique and data triangulation. The analysis of data was conducted using flow analysis i.e, the data reduction, data presentation, and conclutions determination. The results of the study are (1) the intrinsic elements that build the novel Rantau 1 Muara are theme, characterizations, plot, settings, and author's point of view; (2) the emotional conditions experienced by characters in the novel Rantau 1 Muara are influenced by three elements i.e, id, ego, and superego; (3) the value of character education that contained in the novel Rantau 1 Muara there are 13 values including religious, honest, tolerance, discipline, hardwork, independent, curiosity, spirit of nationality, love the country, friendly/ communicate, like reading, concern to social issue, and responsibly; (4) novel Rantau 1 Muara can be used as an alternative teaching material of literary appreciation class in Senior High School level.
\end{abstract}

Keywords: literature psychology, character education value, teaching materials

BASASTRA Jurnal Bahasa, Sastra, dan Pengajarannya

Volume 7 Nomor 1, April 2019, ISSN I2302-6405 


\section{PENDAHULUAN}

Karya sastra merupakan hasil dari sebuah pemikiran maupun ide dan gagasan seseorang. Dalam proses membuat karya sastra, seorang pengarang tidak bisa terlepas dari realitas kehidupannya. Kehidupan manusia dan masalah-masalah yang dihadapinya menjadi sumber inspirasi dalam pembuatan karya sastra tersebut. Pengarang mengungkapkan ide-ide dan pemikirannya dalam sebuah karya sastra yang indah sehingga bisa dinikmati oleh pembacanya. Hal ini sejalan dengan fungsi sastra yakni bisa digunakan sebagai sarana menghibur diri pembaca. Wellek dan Warren (dalam Nurgiyantoro, 2005: 3) menyatakan bahwa membaca sebuah karya sastra fiksi berarti menikmati cerita dan menghibur diri untuk memperoleh kepuasan batin.

Karya sastra dibagi menjadi beberapa bentuk yakni: (1) prosa, yakni bentuk sastra yang diuraikan dengan bahasa yang panjang dan tidak terikat dengan aturan-aturan, (2) puisi, bentuk karya sastra yang menggunakan bahasa yang singkat, padat, dan indah, (3) drama, bentuk karya sastra yang dilukiskan dengan menggunakan bahasa yang bebas dan panjang, serta disajikan menggunakan dialog dan monolog.

Menurut Waluyo (2011: 1) prosa fiksi yaitu jenis prosa yang dihasilkan dari proses imajinasi. Fiksi artinya hasil khayalan atau sesuatu yang sebenarnya tidak ada. Tokoh, peristiwa, dan tempat yang disebut dalam karya tersebut bersifat imajiner. Oleh karena itu, fiksi dapat diartikan sebagai prosa naratif yang bersifat imajiner namun masuk akal dan mengandung kebenaran yang mendramatisasikan hubungan antarmanusia. Walaupun dihasilkan berdasarkan khayalan, karya prosa naratif tetap diambil dari pengalaman pengarang sebagai manusia dalam kehidupan nyata.

Novel merupakan salah satu bentuk karya sastra yang termasuk dalam prosa fiksi. Novel berasal dari bahasa latin novellas, yang terbentuk dari kata novus yang berarti baru atau new dalam bahasa Inggris (Santoso dan Wahyuningtyas, 2010: 46). Novel diartikan sebagai suatu cerita prosa fiktif dengan panjangnya tertentu, yang melukiskan para tokoh, gerak serta adegan kehidupan nyata yang refressentatif dalam suatu alur atau keadaan yang agak kacau atau kusut (Purba, 2010: 62).

Novel menceritakan berbagai masalah kehidupan manusia dalam hubungannya dengan lingkungan dan sesama manusia. Novel mengungkapkan aspek-aspek kemanusiaan yang lebih mendalam dan disajikan dengan halus (Semi, 1993: 32). Pengalaman pengarang dalam kehidupan nyata dituangkan ke dalam cerita melalui tokoh-tokoh yang ada dalam novel. Berbagai konflik atau masalah akan muncul dalam cerita novel tersebut. Masalah yang muncul bisa berupa masalah sosial, agama, politik, perbedaan cara pandang, tekanan batin yang dialami tokoh, maupun berbagai macam problema yang berhubungan dengan kompleksitas kehidupan ini. Masalah kejiwaan yang dialami oleh tokoh dalam novel tersebut dapat dikaji melalui pendekatan psikologi sastra.

Psikologi sastra adalah kajian sastra yang memandang karya sebagai aktivitas kejiwaan. Pengarang akan menggunakan cipta, rasa, dan karya dalam berkarya. Psikologi sastra mengenal karya sastra sebagai pantulan kejiwaan. Pengarang akan menangkap gejala jiwa kemudian diolah ke dalam teks dan dilengkapi dengan kejiwaannya. Karya sastra yang dipandang sebagai fenomena psikologis, akan menampilkan aspek-aspek kejiwaan melalui tokoh-tokoh (Endraswara: 2003: 96).

Ratna (2013: 343) mengatakan bahwa pada dasarnya psikologi sastra memberikan perhatian pada unsur-unsur kejiwaan tokoh-tokoh fiksional yang terkandung dalam karya. Sebagai dunia dalam kata karya sastra memasukkan berbagai aspek kehidupan ke dalamnya, 
khususnya manusia. Pada umumnya, aspek-aspek kemanusiaan inilah yang merupakan objek utama psikologi sastra, sebab semata-mata dalam diri manusia itulah, sebagai tokoh-tokoh, aspek kejiwaan dicangkokkan dan diinvestasikan. Dalam analisis, pada umumnya yang menjadi tujuan adalah tokoh utama, tokoh kedua, tokoh ketiga, dan seterusnya. Selanjutnya, ia menyebutkan bahwa tujuan psikologi sastra adalah memahami aspekaspek kejiwaan yang terkandung dalam suatu karya.

Menurut Freud, seorang neurolog yang berasal dari Austria, ia membagi kepribadian manusia menjadi tiga yakni $i d$, ego, dan superego. Id adalah aspek kepribadian yang 'gelap' dalam bawah sadar manusia yang berisi insting dan nafsu, tidak kenal nilai dan agaknya berupa energi buta (Jatman, 1997: 57). Id adalah aspek biologis yang merupakan sistem asli dalam kepribadian, dari sini aspek kepribadian yang lain tumbuh. Id berisikan hal-hal yang dibawa sejak lahir dan yang menjadi pedoman id dalam berfungsi adalah menghindarkan diri dari ketidakenakan dan mengejar kenikmatan (Suryabrata, 1993: 145).

Freud (dalam Koeswara, 1991: 34) berpendapat ego terbentuk pada struktur kepribadian individu sebagai kontak dunia luar. Ego dikuasai prinsip realita tempat pada pemikiran yang sesuai dengan tuntunan sosial yang rasional dan mengungkapkan diri melalui bahasa. Ego (terletak di antara alam sadar dan taksadar) yang bertugas sebagai penengah yang mendamaikan tuntutan pulsi dan larangan superego (Minderop, 2013: 21).

Superego mengacu pada moralitas dalam kepribadian. Superego sama halnya dengan hati nurani yang mengenali nilai baik dan buruk. Sebagaimana id, superego tidak mempertimbangkan realitas karena tidak bergumul dengan hal-hal realistis, kecuali ketika impuls seksual dan agresivitas id dapat terpuaskan dalam pertimbangan moral (Minderop, 2013: 22). Ketiga sistem kepribadian tersebut (id, ego, superego) satu sama lain saling berkaitan serta membentuk totalitas dan tingkah laku manusia yang tak lain merupakan produk interaksi ketiganya (Endraswara, 2003: 101).

Kajian psikologi sastra digunakan untuk menganalisis konflik batin yang dialami oleh tokoh yang ada dalam novel Rantau 1 Muara karya Ahmad Fuadi. Teori yang digunakan adalah teori Sigmund Freud yang akan mengkaji tentang kondisi psikis tokoh yang digambarkan dalam novel tersebut. Novel Rantau 1 Muara merupakan novel ketiga dari trilogi Negeri 5 Menara karya Ahmad Fuadi yang diterbitkan pertama kali pada tahun 2013. Novel Rantau 1 Muara berisi tentang perjuangan dan pencarian makna hidup tokoh utamanya yakni Alif. Ia merupakan anak kampung dari pinggiran Danau Maninjau yang bermimpi dapat sekolah dan bekerja di luar negeri. Dengan usaha dan latihan yang tiada henti berhasil mengantarkan Alif meraih mimpinya.

Selain mengkaji tentang psikologi sastra, penelitian ini juga akan mengkaji tentang nilai-nilai pendidikan. Hal ini dikarenakan kurikulum 2013 yang berusaha mengintegrasikan nilai-nilai pendidikan karakter ke dalam setiap mata pelajaran seperti yang dikemukakan oleh Fadlillah (2014: 16) bahwa kurikulum 2013 berusaha untuk lebih menanamkan nilai-nilai yang tercermin pada sikap dapat berbanding lurus dengan keterampilan yang diperoleh peserta didik melalui pengetahuan di bangku sekolah.

Melalui pembelajaran novel siswa diharapkan mampu mengambil nilai karakter yang ada dalam novel tersebut melalui jalan cerita maupun karakter dari tokoh-tokohnya. Melalui pengajaran sastra format pendidikan karakter akan lebih konkrit sehingga berguna bagi peserta didik, dan dapat dioperasionalkan dalam hidup keseharian mereka secara praktis dalam bentuk keberpihakan terhadap nilainilai yang positif dan mampu menghargai perbedaan orang lain atau kultur lain tanpa 
harus mengerutkan dahi (Ismawati, 2013: 115-116).

Tujuan dari penelitian ini adalah mendeskripsikan unsur intrinsik novel Rantau 1 Muara karya Ahmad Fuadi, kondisi psikis tokoh yang digambarkan dalam novel Rantau 1 Muara karya Ahmad Fuadi menurut teori Sigmund Freud, nilai-nilai pendidikan karakter yang terdapat dalam novel Rantau 1 Muara karya Ahmad Fuadi, serta relevansi novel Rantau 1 Muara karya Ahmad Fuadi sebagai materi ajar apresiasi sastra di SMA.

\section{METODE PENELITIAN}

Penelitian ini menggunakan metode kualitatif deskriptif yang berarti metode tersebut terurai dalam bentuk kata-kata yang menghasilkan data deskriptif berupa kata-kata tertulis atau lisan dari orangorang dan perilaku yang dapat diamati. Pendekatan yang digunakan adalah pendekatan psikologi sastra. Data yang digunakan dalam penelitian ini adalah kata-kata, kalimat, maupun paragraf yang ada dalam novel Rantau 1 Muara. Sedangkan sumber data berupa teks novel Rantau 1 Muara, guru Bahasa Indonesia, dan siswa kelas XII.

Teknik pengambilan sampel dalam penelitian ini menggunakan purposive sampling. Teknik pengumpulan data berupa analisis dokumen dan wawancara mendalam. Teknik uji validitas data mengunakan triangulasi teori dan triangulasi data. Teknik analisis data menggunakan teknik analisis mengalir yakni berupa reduksi data, penyajian data, dan penarikan simpulan.

\section{HASIL DAN PEMBAHASAN}

\section{Unsur Intrinsik Novel Rantau 1 Muara}

Tema dalam novel Rantau 1 Muara adalah tentang pencarian makna hidup. Alif sedang mencari-cari apa artinya hidup. Dengan bertualang keliling dunia, ia tahu makna hidup sesungguhnya. Hidup itu bukan tentang materi maupun jabatan, tetapi hidup itu adalah tentang menjadi hamba yang berkewajiban beribadah kepada Tuhan dan menjadi khalifah yang berkewajiban memberikan manfaat untuk semua makhluk. Hidup itu seperti perantauan. Nantinya ia akan bermuara pada yang satu, yakni Tuhan Yang Esa.

Tokoh utama dalam novel Rantau 1 Muara adalah Alif. Sedangkan tokoh tambahan yang terdapat dalam novel diantaranya Dinara, Pasus, Randai, Amak, Mas Garuda, Mas Aji, Mas Malaka, Putu, Yansen, Faizal, Hana, Ibu Kos, Raisa, Uda Ramon, Papa Dinara, Mama Dinara, Bang Togar, Ustad Fariz, Mas Nanda, Mbak Hilda, Rio, Diana, Arum, Tere, penagih hutang, petugas rapat kontraktor, Belle, Dida, petugas kamar jenazah, Sapta, Jenderla Broto, ajudan Jenderal Broto, Profesor Deutsch, Andreww Roddick, Tom Watson, Raja, Atang, Mas Rama, dan Gary Owen.

Novel Rantau 1 Muara ini menggunakan alur lurus atau progresif. Cerita dimulai dari tahap awal berupa penyituasian, pengenalan, pemunculan konflik, tahap tengah berupa konflik yang meningkat dan klimaks, dan tahap akhir yakni penyelesaian. Latar yang terdapat dalam novel ini dibagi menjadi tiga yaitu latar tempat, latar waktu, dan latar sosial. Latar tempat terdiri dari kota Bandung, Jakarta, kampung Bayur, Washington DC, New York, dan London. Latar waktu yang berupa tanggal misalnya 9 Maret 1998, berupa nama hari misalnya Senin, berupa penunjuk waktu misalnya pagi, siang, sore, dan malam, serta penunjuk jam seperti jam 2 siang. Selain itu juga menggunakan katakata seperti musim semi, sebelum azan Subuh, dan sehabis magrib. Latar sosial berupa latar belakang Alif yang sarat dengan nilai-nilai religius. Pengarang menggunakan sudut pandang "aku" sebagai tokoh utama yang berarti pengarang terlibat langsung dalam jalannya cerita.

Kondisi Psikis Tokoh Menurut Teori Sigmund Freud 
Freud membagi psikisme manusia menjadi tiga yaitu $i d$, ego, dan superego. Id adalah sistem kepribadian manusia yang paling dasar. $I d$ tidak dapat dimusnahkan, hanya dapat dikawal dan di dalam tidur sebagian sering menjelma kembali (Semi, 1993: 67). Id adalah segi kepribadian tertua, sistem kepribadian pertama, ada sejak lahir (bahkan mungkin sebelum lahir), diturunkan secara genetis, langsung berkaitan dengan dorongan-dorongan biologis dan merupakan sumber/ cadangan energi manusia sehingga juga dikatakan oleh Freud sebagai jembatan antara segi biologis dan psikis manusia (Moesono, 2003: 3).

Alif merupakan tokoh utama yang terdapat dalam novel Rantau 1 Muara. Ia berasal dari keluarga yang sederhana. Dari latar belakang tersebut, Alif berkeinginan untuk meningkatkan harkat dirinya dengan berusaha keras dan sungguh-sungguh. Id dapat dilihat dari keinginan Alif untuk meningkatkan harkat dirinya tersebut. Berikut kutipan yang menunjukkan id Alif. ... Berapa ratus malam sepi yang aku habiskan sampai dini hari untuk mengasah kemampuanku, belajar, membaca, menulis, dan berlatih tanpa henti. Melebihkan usaha di atas rata-rata orang lain agar aku bisa meningkatkan harkat diriku. (Fuadi, 2013: 8)

Selain keinginan Alif untuk meningkatkan harkat dirinya, id juga dapat dilihat dari sikap Alif yang tidak ingin diremehkan oleh Randai, tidak ingin malu karena ditolak oleh perusahaan di Jakarta, keinginan mendapatkan gaji yang besar, keinginan membalas seseorang yang telah membuatnya tersinggung, dan merasa senang dengan jabatan, materi, serta kebebasan yang ia miliki.

Ego berada di antara dua kekuatan yang bertentangan dan dijaga serta patuh pada prinsip realitas dengan mencoba memenuhi kesenangan individu yang dibatasi oleh realitas. Ego menolong manusia untuk mempertimbangkan apakah ia dapat memuaskan diri tanpa mengakibatkan kesulitan atau penderitaan bagi dirinya sendiri. Tugas ego memberi tempata pada fungsi mental utama, misalnya: penalaran, penyelesaian masalah, dan pengambilan keputusan (Minderop, 2013: 22).

Id Alif yang mengatakan bahwa ia ingin meningkatkan harkat dirinya mendorong egonya untuk mengasah kemampuan dengan belajar, membaca, menulis, dan berlatih tiada henti. ia teringat dengan kata pepatah 'Jika kau bukan anak raja dan juga bukan anak ulama besar, maka menulislah'. Hal tersebut dapat dilihat pada kutipan berikut ini.

Mungkin benar juga kata pepatah yang konon berasal dari Imam AlGhazali, "Jika kau bukan anak raja dan juga bukan anak ulama besar, maka menulislah". Aku bukan anak orang kaya, bukan anak orang berkuasa, dan bukan pula anak orang terpandang, maka menulis sajalah yang harus aku lakukan. (Fuadi, 2013: 9)

Ego Alif muncul saat Alif tidak mau diremehkan oleh Randai dan merasa kesal pada Randai yang memojokkan dirinya karena Alif belum mendapat pekerjaan juga. Ego pada diri Alif berhasil meredam $i d n y a$ tersebut dengan berniat mengalahkan Randai. Selain itu, ego juga dapat dilihat ketika Alif berencana akan tetap pergi ke Jakarta. Hal itu disebabkan idnya yang tidak ingin malu karena ia ditolak oleh perusahaan di Jakarta padahal ia sudah terlanjur pamit kepada teman-temannya.

Superego (penuntun moral dan aspirasi seseorang) berfungsi sebagai tapisan atau saringan yang menolak sesuatu yang melanggar prinsip moral, yang menyebabkan seseorang mempunyai sifat malu atau merasa senang terhadap sesuatu yang baik dan terpuji (Semi, 1993: 67). Id Alif yang mengatakan bahwa ia ingin meningkatkan harkat dirinya mendorong ego untuk mengasah kemampuan dengan berlatih tiada henti. 
Superego Alif membenarkan apa yang dilakukannya.

Alif mendapat tugas pertama dari kantornya untuk meliput rapat kontraktor proyek pemerintah. Di sana, ia diberi amplop yang berisi uang dari petugas rapat. Ia tergiur untuk menerima amplop tersebut. Uang itu bisa ia gunakan untuk ongkos makan atau transport. Namun ia teringat dengan pesan Mas Aji, atasannya yang melarang anak buahnya untuk menerima amplop yang berasal dari liputan. Superegonya kemudian menimbang-nimbang apakah ia akan menerima atau menolak amplop tersebut. Akhirnya ia memilih untuk menolaknya karena menurut Alif pilihan tersebut adalah benar. Hal tersebut dapat dilihat pada kutipan berikut ini.

Setelah acara selesai aku menemui laki-laki bersafari tadi. Ragu sejenak, tapi pada akhirnya aku mengangsurkan juga amplop itu kembali ke dia. "Maaf Pak, saya gak usah.” (Fuadi, 2013: 61)

$I d$, ego, superego, merupakan aspek kepribadian yang saling berkesinambungan dalam diri seorang tokoh. Ketiga sistem kepribadian manusia yang berupa id, ego, dan superego mempengaruhi struktur kepribadian dan konflik kejiwaan yang dialami oleh tokoh utama. Hal tersebut seperti dalam penelitian yang dilakukan oleh Ekayani, Rohmadi, dan Waluyo (2017) yang menyimpulkan bahwa kondisi kejiwaan tokoh utama diperoleh dari jabaran penokohan yang terdapat dari unsur-unsur intrinsik yang ada. Terdapat tiga aspek kejiwaan dalam novel meliputi $i d$, ego, dan superego. Ketiga aspek tersebut berkesinambungan dalam diri tokoh utama.

Dalam novel ini ada beberapa $i d$, ego, dan superego tokoh-tokohnya yang berjalan seimbang. Misalnya Id Alif yang mengatakan bahwa ia ingin meningkatkan harkat dirinya. Oleh karena itu, ia mengasah kemampuannya dengan belajar, membaca, menulis, dan berlatih tiada henti. Ia teringat dengan kata pepatah 'Jika kau bukan anak raja dan juga bukan anak ulama besar, maka menulislah' (ego). Superego Alif membenarkan apa yang dilakukannya. Ia bukan anak raja dan ulama besar, maka hanya dengan menulislah ia bisa meningkatkan harkat dirinya.

Selain itu, ada $i d$, ego, dan superego yang berjalan tidak seimbang. Superegonya mengatakan bahwa idnya adalah salah. Hal tersebut terjadi saat krisis moneter yang melanda Indonesia berdampak pula pada Alif. Ia kehilangan sumber penghasilan dari pekerjaannya menulis kolom. Id Alif yang ingin memenuhi kebutuhan hidupnya dan keluarganya mendorong ego berupa rencana menarik uang dari kartu kredit. Superego mengatakan bahwa perbuatannya tidak benar. Tetapi ia tidak punya pilihan lain. Ia harus melakukan demi memenuhi kebutuhannya. Secara keseluruhan, id, ego, dan superego Alif berjalan secara beriringan sehingga Alif termasuk sebagai manusia wajar.

\section{Nilai-Nilai Pendidikan Karakter}

Nilai pendidikan karakter menurut Kemdiknas adalah pendidikan yang menanamkan dan mengembangkan karakter-karakter luhur kepada peserta didik, sehingga mereka memiliki karakter luhur itu, menerapkan dan mempraktikkan dalam kehidupannya, entah dalam keluarga, sebagai anggota masyarakat dan warga Negara (dalam Wibowo, 2013: 13). Salah satu cara untuk menanamkan siswa nilai-nilai pendidikan karakter adalah melalui karya sastra. Hal itu disampaikan oleh Semi (1993: 194) bahwa dengan mempelajari sastra, diharapkan siswa mempunyai pengetahuan yang baik tentang manusia dan kemanusiaan, mengenal nilai, dan mendapatkan ide-ide baru. Nilai-nilai pendidikan karakter yang ada pada novel Rantau 1 Muara ada 13 karakter diantaranya religius, jujur, toleransi, disiplin, kerja keras, mandiri, rasa ingin tahu, semangat kebangsaan, cinta tanah air, 
menghargai prestasi, bersahabat/ komunikasi, gemar membaca, peduli sosial, dan tanggung jawab.

Nilai religius, dicerminkan oleh Alif yang lahir dari keluarga yang taat beragama. Ia juga pernah sekolah mondok di Pondok Madani selama empat tahun. Hal itu membuatnya selalu melaksanakan kewajiban-kewajibannya sebagai seorang muslim, seperti salat, membaca Alquran, dan berdoa. Berada di wilayah yang mayoritas non muslim tidak membuat Alif melupakan kewajibannya sebagai hamba Tuhan. Ia tetap melaksanakan kewajibannya seperti salat, puasa, dan menghadiri kajian-kajian Islam. Selain Alif, nilai tersebut juga ditunjukkan oleh Amak yang meniatkan segala sesuatu hanya demi Tuhan. Nilai kejujuran tergambar pada diri Dinara. Hal ini dilihat saat ia menjawab pertanyaan Alif. Meskipun ia tidak tahu, ia tetap mengatakan tidak tahu. Ia tidak harus merasa tidak enak mengatakan tidak. Dinara merupakan gadis Jakarta yang menjadi teman kerja Alif di Derap.

Nilai toleransi yang berarti menghargai perbedaan. Hal ini tercermin pada saat kegiatan salat Jumat di kampus GWU. Pihak gereja mau meminjamkan tempatnya untuk kegiatan salat Jumat masyarakat muslim karena kapasitas ruangan yang lain tidak bisa lagi digunakan untuk tempat salat Jumat. Alasan memilih ruangan tersebut karena tidak ada ruangan lain lagi selain gereja tersebut yang bisa digunakan secara nyaman untuk melaksanakan salat Jumat.

Nilai disiplin, tergambar pada diri Mas Aji dan Alif. Mas Aji menggambaran sosoknya yang disiplin terhadap waktu. Ia tidak menyukai keterlambatan. Setiap wartawan yang terlambat mengikuti rapat, pasti akan mendapatkan hukuman dari Mas Aji. Sedangkan Alif disiplin tindakan yakni berusaha patuh terhadap aturan yang sudah ditetapkan saat ia mengerjakan tugas dari Derap. Ia menolak diberi amplop dari rapat kontraktor saat ia meliput berita. Ia patuh terhadap peraturan kantor yang melarang wartawannya menerima sogokan dalam bentuk apapun.

Nilai kerja keras sangat kental dalam novel ini. Tokoh yang mempunyai sifat kerja keras paling menonjol adalah Alif dan Mas Garuda. Alif bekerja keras dalam meraih mimpinya. Ia belajar, berlatih, menulis tiada henti untuk mengasah kemampuannya. Saat ingin meraih beasiswa S-2 di luar negeri, Alif berusaha keras belajar TOEFL dengan membacanya setiap malam sebelum tidur. Kerja keras Mas Garuda dilihat dari banyaknya waktu yang ia gunakan untuk bekerja demi tabungannya untuk pulang ke tanah air. Ia rela bekerja menjadi apa saja dan bekerja hampir 24 jam setiap harinya.

Nilai mandiri, dilihat dari diri Dinara. Meskipun ia berasal dari keluarga yang mampu, ia sudah terbiasa mandiri sejak kuliah. Ia menjadi penyiar radio saat kuliah. Ia juga memilih bekerja di Derap walaupun ia sudah ditawari kerja di perusahaan lain yang mempunyai posisi dan gaji yang lebih menjanjikan. Nilai mandiri juga diperlihatkan oleh Alif karena sejak ayahnya meninggal, ia berusaha mencukupi kebutuhan dirinya sendiri dan keluarganya. Ia tidak mau bergantung pada siapapun.

Nilai rasa ingin tahu diperlihatkan oleh Alif dan Pasus. Di sela-sela kesibukannya, mereka ingin belajar cara menulis yang baik dari redaktur senior. Ketika pekerjaan sudah selesai mereka mengintip para redaktur yang sedang menulis berita. Mereka berharap dapat menulis berita yang baik dan menarik seperti yang dilakukan oleh seniornya.

Nilai semangat kebangsaan dicerminkan oleh Raja dan Atang. Mereka memilih untuk pulang ke tanah air untuk mengamalkan ilmu yang telah diperoleh dari berkelana di luar negeri demi bangsanya meskipun mereka sudah hidup nyaman di luar negeri. Selain Raja dan Atang, semangat kebangsaan juga dicerminkan oleh Dinara. Ia merasa bahwa ia lebih dibutuhkan oleh tanah airnya daripada Negara tempat ia tinggal. Di 
tanah airnya, ia bisa menerapan ilmu yang telah ia dapat dari luar negeri.

Nilai cinta tanah air ditunjukkan oleh Alif saat dia baru saja pulang dari Kanada dan memasang bendera merah putih di dinding kamarnya. Ia merasa bangga bisa mewakili Indonesia untuk tampil di dunia internasional. Selain itu, juga tercermin saat Alif dan Dinara menggunakan pakaian adat Jawa untuk akad nikah dan pakaian adat Minang untuk resepsinya.

Nilai bersahabat/ komunikasi digambarkan oleh Alif yang masih menjalin komunikasi dengan Atang dan Raja meskipun mereka sudah lama tidak bertemu. Selain itu, Alif juga mau bersahabat dengan Belle, wartawan asing yang bekerja di Indonesia. Ia menerima tawarannya untuk bertemu di sebuah restoran yang biasa digunakan berkumpul oleh wartawan asing.

Nilai gemar membaca ditunjukkan oleh Alif. Ia digambarkan gemar membaca saat kecil. Banyak buku maupun majalah yang sudah ia tamatkan. Biasanya ia juga membaca buku sebelum tidur. Gemar membaca membuatnya bisa mewujudkan mimpi-mimpinya. Dari membaca, ia berhasil meraih kesempatan untuk menjadi peserta pertukaran pelajar ke luar negeri, diminta untuk menulis kolom pada beberapa kantor berita sehingga sebelum ia lulus ia sudah mendapatkan gaji yang besar. Gemar membaca juga mengantarkan Alif meraih impiannya untuk belajar dan bekerja di luar negeri.

Nilai peduli sosial dicerminkan oleh Mas Garuda. Ia sangat suka membantu orang lain walaupun ia belum kenal. Ia juga yang membantu Alif saat Alif baru saja tiba di Amerika dan mencari tempat tinggal. Saat Alif sakit, Mas Garuda pula yang merawat Alif hingga ia merasa menjadi lebih baik. Di saat orang lain menyelamatkan dirinya sendiri pada tragedi teror yang merubuhkan gedung WTC di New York, rasa peduli sosial mendorong Mas Garuda menology orang lain terlebih dahulu.
Nilai tanggung jawab dapat dilihat dari sosok Alif yang mampu menghidupi Amak dan kedua adiknya. Setelah kepergian ayahnya, Alif lah yang menjadi tulang punggung untuk keluarganya. Hal itu yang menjadikan Alif bekerja keras memenuhi kebutuhan keluarganya tersebut.

\section{Relevansinya sebagai Materi Ajar Apresiasi Sastra di SMA}

Novel merupakan salah satu materi ajar yang digunakan untuk mempelajari sastra. Salah satu alasan novel dijadikan sebagai materi ajar adalah cukup mudahnya karya tersebut dinikmati siswa sesuai dengan kemampuannya. Pada kurikulum 2013, novel diajarkan pada siswa kelas XII. Hal tersebut dapat dilihat pada kompetensi dasar/ KD (3.3) Menganalisis teks cerita sejarah, berita, iklan, editorial/ opini, dan novel baik melalui tulisan maupun tulisan. Sesuai KD tersebut, siswa diharapkan mampu menganalisis novel terkait dengan unsurunsur pembangun novel yang meliputi unsur intrinsik dan unsur ekstrinsik.

Rahmanto (1988: 27) menyebutkan ada tiga aspek yang perlu dipertimbangkan yakni aspek bahasa, psikologi, dan latar belakang budaya. Ketiga hal tersebut yakni bahasa, psikologi, dan latar belakang budaya yang terdapat dalam novel Rantau 1 Muara ini juga sesuai dengan tingkatan siswa SMA. Bahasa yang digunakan mudah dipahami oleh siswa. Dari segi psikologi, novel ini sesuai dengan siswa karena novel ini bercerita tentang seorang penuntut ilmu yang sama halnya dengan seorang siswa. Selain itu, novel ini tidak mengandung unsur pornografi maupun hal negatif lainnya. Latar belakang Alif yang merupakan seorang mahasiswa yang punya mimpi untuk sekolah ke luar negeri dapat memberikan motivasi kepada siswa untuk mempunyai impian yang tinggi dan berusaha mewujudkan dengan usaha yang semaksimal mungkin.

Novel merupakan cara efektif dalam memberikan pendidikan karakter kepada 
siswa. Novel Rantau 1 Muara merupakan novel yang banyak terdapat pendidikan karakter sehingga sesuai untuk dijadikan sebagai materi ajar. Novel ini terdapat tiga belas nilai-nilai pendidikan karakter dari total depan belas yang disampaikan oleh Kemendikbud. Ketiga belas nilai tersebut adalah religius, jujur, toleransi, disiplin, kerja keras, mandiri, rasa ingin tahu, semangat kebangsaan, cinta tanah air, menghargai prestasi, bersahabat/ komunikasi, gemar membaca, peduli sosial, dan tanggung jawab. Dari penjelasan tersebut bisa dikatakan bahwa Novel Rantau 1 Muara layak dijadikan sebagai materi ajar apresiasi sastra di SMA.

\section{SIMPULAN}

Dari penjelasan yang telah diuraikan di atas, dapat disimpulkan bahwa novel Rantau 1 Muara mengandung unsur intrinsik berupa tema, penokohan, alur, latar, dan sudut pandang pengarang.

\section{REFERENSI}

Ekayani, P., Rohmadi, M., \& Waluyo, B. (2017). Konflik Batin Tokoh Utama dan Nilai Pendidikan Karakter Novel Kuantar ke Gerbang Karya Ramadhan K.H. Jurnal BASASTRA, 5 (1), 132-139).

Endraswara, S. (2003). Metodologi Penelitian Sastra. Yogyakarta: Pustaka Widyatama.

Fadlillah, M. (2014). Implementasi Kurikulum 2013 dalam Pembelajaran SD/ MI, SMP/ MTs, dan SMA/ MA. Yogyakarta: Ar-Ruzz Media.

Fuadi, A. (2013). Rantau 1 Muara. Jakarta: Gramedia Pustaka Utama.

Ismawati, E. (2013). Pengajaran Sastra. Yogyakarta: Penerbit Ombak.

Jatman, D. (1997). Psikologi Jawa. Yogyakarta: Yayasan Bentang Budaya.

Koeswara, E. (1991). Teori-Teori Kepribadian. Bandung: PT Eresco.
Penelitian ini menggunakan teori psikologi dari Sigmund Freud yang membagi kepribadian manusia menjadi tiga yaitu $i d$, ego, dan superego. Ketiga sistem kepribadian manusia yang berupa $i d$, ego, dan superego mempengaruhi struktur kepribadian dan konflik kejiwaan yang dialami oleh tokoh utama. Secara keseluruhan, dapat dikatakan bahwa kepribadian Alif merupakan kepribadian yang wajar karena $i d$, ego, dan superego Alif dapat berjalan secara seimbang.

Terdapatnya tiga belas nilai pendidikan karakter dari delapan belas yang disebutkan oleh Kemendiknas, membuat Novel Rantau 1 Muara layak dijadikan sebagai materi ajar apresiasi sastra di SMA. Ketiga belas nilai tersebut adalah religius, jujur, toleransi, disiplin, kerja keras, mandiri, rasa ingin tahu, semangat kebangsaan, cinta tanah air, menghargai prestasi, bersahabat/ komunikasi, gemar membaca, peduli sosial, dan tanggung jawab.

Minderop, A. (2013). Psikologi Sastra: Karya Sastra, Metode, Teori, dan Contoh Kasus. Jakarta: Yayasan Pustaka Obor Indonesia.

Moesono, A. (2003). Psikoanalisis dan Sastra. Depok: Pusat Peneliti Kemasyarakatan dan Budaya Lembaga Penelitian Universitas Indonesia.

Nurgiyantoro, B. (2005). Teori Pengkajian Fiksi. Yogyakarta: Gadjah Mada University Press.

Purba, A. (2010). Sastra Indonesia Kontemporer. Yogyakarta: Graha Ilmu.

Rahmanto, B. (1988). Metode Pengajaran Sastra. Yogyakarta: Penerbit Kanisius.

Ratna, N. K. (2013). Teori, Metode, dan Teknik Penelitian Sastra. Yogyakarta: Pustaka Pelajar. 
Santosa, W.H. dan Wahyuningtyas, S. Waluyo, H. J. (2011). Pengkajian dan (2010). Pengantar Apresiasi Prosa. Surakarta: Yuma Pustaka. Apresiasi Prosa Fiksi. Surakarta: UNS Press.

Semi, M. A. (1993). Anatomi Sastra. Wibowo, A. (2013). Manajemen Padang: Penerbit Angkasa Raya.

Suryabrata, S. (1993). Psikologi Pendidikan. Jakarta: Raja Grafindo Persada.

Pendidikan Karakter di Sekolah (Konsep dan Praktik Implementasi). Yogyakarta: Pustaka Pelajar. 